\title{
Keep on walking: the role of migration in Linearbandkeramik life
}

\author{
Daniela Hofmann \\ Institute of Archaeology, University of Hamburg, Hamburg, DE \\ daniela.hofmann@uni-hamburg.de
}

\begin{abstract}
Migration played a central role throughout the LBK culture. After summarising the motivations for migration in the earliest $L B K$, the article outlines how some of these factors remained relevant in later phases. Beyond continued west-and eastward expansion, at regional and site levels migration to better one's social position provided an alternative to patrilineal land inheritance. The main change between the earliest and later phases is the role of material culture after migration events. Initially a means of creating long-distance connections, it later stressed difference from other groups. This process of ethnogenesis is invisible genetically. Overall, migration emerges as a salient behaviour even in 'sedentary' Neolithic societies.
\end{abstract}

IZVLEČEK - Migracije so imele osrednjo vlogo čez celotno obdobje kulture LTK. V članku povzemamo motivacije za migracije $v$ času najzgodnejše LTK, nato pa se osredotočamo predvsem na načine, kako so nekateri motivacijski dejavniki ostali pomembni tudi v kasnejših fazah. Poleg stalne širitve od zahoda proti vzhodu predstavlja migracija zaradi izboljšanja osebnega družbenega statusa na regionalnem nivoju in na ravni najdišč pomembno alternativo patrilinearnemu dedovanju zemlje. Glavno razliko med zgodnimi in poznimi fazami kulture LTK vidimo v vlogi materialne kulture po migracijskih dogodkih. Sprva je bila materialna kultura sredstvo za ustvarjanje povezav na dolge razdalje, kasneje pa so se s pomočjo materialne kulture posebej izpostavile razlike med posameznimi skupinami. Ta proces etnogenete je neviden za genetske raziskave. Na splošno se migracije pojavijo kot glavni vzorci obnašanja tudi v 'sedentarnih' neolitskih skupnostih.

KEY WORDS - Linearbandkeramik (LBK); migration; aDNA; ethnogenesis; social status

\section{Introduction}

As the first Neolithic culture over vast areas of central and western Europe (Fig. 1), the Linearbandkeramik (LBK) has long been in the spotlight. The question of its initial spread has been particularly controversially discussed, with opinion oscillating from population movement (Childe 1929; Lüning $1988)$ to indigenous adoption as the main driver (Barker 2006.361-363; Whittle 1996.363-364) and back again to a model of leapfrog colonisation, whereby small groups of colonists create isolated pioneer sites, inspiring locals to follow suit (e.g., Anthony 1990.902-903; Gronenborn 1999). In the last few years, archaeogenetic studies (e.g., Brandt et al. 2013; Haak et al. 2012; Szécsényi-Nagy et al. 2014) have altered our perception yet again, indicating very strongly that LBK expansion was effected by large groups of colonisers, genetically very different from the European hunter-gatherer population, with whom they appear to have interbred surprisingly little.

Even though this scenario is now gaining more widespread acceptance, the role of group migration - i.e. a permanent shift of residence of a social unit larger than an individual - after initial colonisation events is still barely discussed. It is acknowledged that individuals could move, and that some covered longer distances. Based on isotopic studies, it seems that LBK women were more likely than men to have been born away from the place in which they were buried, a pattern interpreted as indicating patrilocality (Hedges et al. 2013.367-368). In other cases, small temporarily mobile groups have been postu- 
lated, but have been seen as effectively tethered to, and based in, permanent settlements. For instance, non-local isotopic signatures reflecting the movement patterns of boys in their teens could be connected to longer periods spent away from settlements, perhaps for seasonal herding (e.g., Bentley et al. 2003).

This paper argues that, in addition to these kinds of mobility (here defined as episodes of movement by groups or individuals which are ultimately centred on a fixed place of residence), migration had an important part to play in LBK society beyond the initial earliest LBK spread. Using selected ethnographic analogies to open a new perspective on the archaeological evidence, it is argued that migration events took place at various spatial scales throughout the duration of the LBK, and that this behaviour left profound traces in LBK worldviews.

Appreciating the role of continued migration events has several consequences. First, it highlights that alternative lifeways and possibilities of gaining status and renown existed in Neolithic societies. Our (generally quite rigid) social models should take into account the flexibility and tension resulting from this, as well as the likely regional and chronological oscillations in the importance of migration. Second, while archaeogenetic results have put the relationship between migration and ethnicity back on the agenda, we must appreciate that migration episodes which took place within the LBK area will

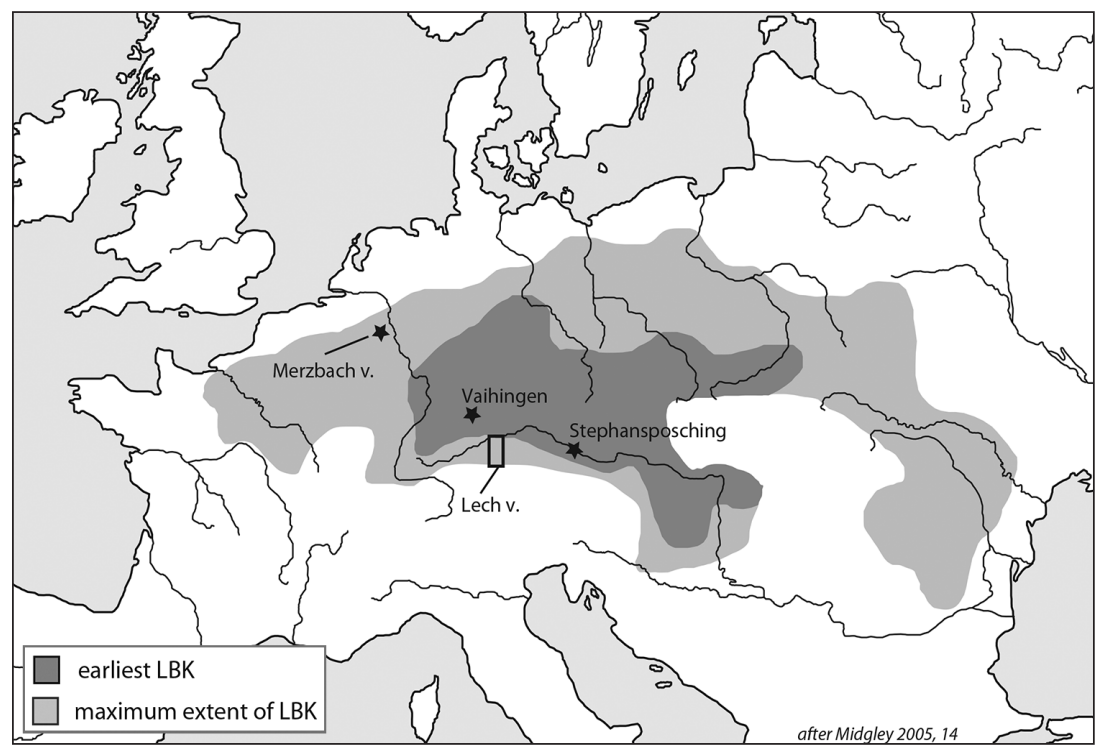

Fig. 1. Map of LBK distribution, showing main sites and areas mentioned in the text. Base map after Midgley (2005.14).

\section{Background}

be largely indistinguishable at a molecular level. Identifying ethnicity and other identity groups is thus largely an archaeological task, and they cannot be simplistically correlated with haplogroups or isotopic signatures. Finally, the continued importance of physical relocation in what we call Neolithic 'sedentary' societies must be appreciated anew. This involves developing a perspective that does not automatically equate any form of mobility or migration to a 'Mesolithic' heritage1.

Migration as an explanation for material culture patterns has had a patchy history in archaeological interpretation in general, fading in and out of fashion (e.g., Anthony 1990; Burmeister 2000; Chapman, Hamerow 1997; Härke 1998). In particular, the link between migration, past ethnic identity and the heuristic device of 'archaeological cultures' has been repeatedly questioned (most recently, e.g., Hu 2013; Siegmund 2014; Sommer 2003). This is not the place to repeat these arguments in detail, but as all these scholars have developed different agendas and approaches, a few words are necessary to situate the line taken in this paper.

Two broad themes emerge from the literature. On the one hand, the problem is how to identify migration archaeologically and distinguish it reliably from other processes (e.g., Andresen 2004; Burmeister 2000). In the end, this identification can only proceed contextually and in terms of greater or lesser probability (Sommer 2003). The second main strand is to understand migration as a cultural behaviour and to reconstruct how it is embedded in a given social formation. This broadly ties in with a wider 'mobility turn' in the social sciences, which has increasingly criticised 'sedentarist' assumptions of stability, centred on dwelling in a fixed place. Yet rather than just replacing this with narratives of an all-pervasive fluidity, the goal is to investigate the factors encou-

1 This is why the relations between LBK famers and Mesolithic hunter-gatherers, although an important research area that has seen considerable new information emerge recently (e.g., Bollongino et al. 2013), are not the focus of the present article. 
raging particular kinds of movements of people, goods and information, the ways societies deal with distance and travel, practices of creating 'home' in mobile contexts, the changing constitution of places and paths, and the varied access to, or exclusion from, the opportunity to move (e.g., Hannam et al. 2006; Kaufmann et al. 2004; Urry 2007).

In the LBK situation, evidence from ancient DNA has now established that in all likelihood, a large-scale migration did take place in conjunction with the appearance of LBK material culture (for discussion of the remaining uncertainties, see Hofmann 2015). It has also been shown that the new LBK-related genetic make-up, which is very different to known hunter-gatherer genomes dominated by $\mathrm{U}$ haplogroups, is closely related to Neolithic populations in Hungary (Szécsényi-Nagy et al. 2014), confirming the source area previously suggested on archaeological grounds (e.g., Bánffy 2004.353-358). The main problem is thus no longer how to identify migration, and this paper instead focuses on the second of the themes discussed above, which has so far hardly been tackled for the LBK. This includes the social mechanisms involved in migration events, both in terms of organising and carrying out a given migration episode, and in terms of the interactions and adjustments necessary at the new settlement location. It also covers processes of ethnogenesis, or the creation of new group identities partly connected to a shared origin or history, and what the role of material culture was in these circumstances. In these contexts, the continued importance of migration as a culturally valued behaviour may have had a longer-lasting impact than has previously been recognised, even though such movements within a shared LBK gene pool cannot yet be traced with aDNA $^{2}$.

A comparative perspective can be useful here and has been adopted for this paper. Although only few analogies have been selected, they have been chosen from societies which present similarities with at least some of the social constellations postulated for the LBK (i.e. inheritance of land in the male line and/or the importance of clans or lineages as units of decision making) and where these similarities are structurally related to aspects of migration. After briefly exploring the possible motivations behind the earliest LBK migration, the bulk of the paper discusses how these factors may have retained a longer-term relevance in later LBK phases, fuelling continued long-distance expansion as well as shorter-distance relocations of various social units.

\section{The hows and whys of earliest LBK migration}

For David W. Anthony (1990.897-899), trying to understand the causes of migrations is too challenging a question, as one would first have to establish at which social level (household, lineage, or larger group) factors promoting migration were actually operating. Causes are also likely to have been complex and multi-layered, and to have included both economic and ideological factors (see also Burmeister 2000.543). Yet, given that the LBK is a comparatively well-investigated archaeological culture, some suggestions can be made.

In general terms, people often migrate because their original homeland has become uninhabitable, for instance as a result of climatic deterioration and resulting food shortages; natural catastrophes; continued warfare and raiding; because of population increase squeezing the resource base; or a combination of these (Anthony 1990.900; Burmeister 2000.543544). While examples can be found for the importance of all these factors, none of these suggestions seem to be the main factor in the LBK. Evidence of large-scale violence is a feature mainly of the end of the LBK (e.g., Gronenborn 2006.17-20), while efforts to link initial LBK expansion to climatic fluctuations (e.g., Strien, Gronenborn 2005.136-139) rely on rather uncertain correlations between climatic data and archaeological events, based on untenably early dates for the earliest LBK. Similarly, while the transition to a Neolithic way of life would almost certainly have caused population increase as the 'Neolithic demographic transition' took hold (Bocquet-Appel 2008), site density in the earliest LBK is thin on the ground in putative areas of origin, so that this is unlikely as the only explanation (e.g., Bánffy 2004. 388; Kalicz 2010.249). This is not to say that long-distance migration, even at an early date, would not have helped to buffer risks (Bogucki 1988.93-128). Yet, even if factors like climatic deterioration, population increase and (perceived) land shortages did play some part in migration events, they are unlikely to provide the full picture, particularly as they cannot explain the very large

2 As whole ancient genomes can now be retrieved (e.g., Gamba et al. 2014; Mathieson et al. 2015), it is possible to identify close biological relatives. However, given the nature of the archaeological resource and the likely extent of sample coverage that can be achieved, the chances of finding close relatives on sites far apart from each other, thereby directly tracing migration routes, are very remote indeed. 
distances covered from the word go, or why settlement needed to be quite so thin. In the search for alternative possibilities, it is worth considering explanations which take into account the particular social conditions prevailing in the LBK and the way settlement communities, households and individuals may have tried to act within them.

\section{Prestige-driven migration}

Several researchers have pointed out the considerable risks, necessary resources and logistical challenges of migration, in particular as the earliest LBK settlements were often located far from their parent sites and each other, and hence from any immediate support network (e.g., Van de Velde 2008; Zimmermann et al. 2005). To begin with, suitable sites would have to be scouted for, generally in territories occupied by hunter-gatherers. Once a spot had been chosen, surplus food for the journey and for surviving the initial weeks at the new settlement would have to be accumulated, alongside enough seed corn and viable herds of domesticates (e.g., Zimmermann et al. 2005.4-6). Especially the latter may have taken some time, as in prehistoric conditions the growth of cattle herds in particular is thought to have been slow (Ebersbach 2002.143-1 $44,161)$. In sum, a colonisation venture certainly did not come cheap and would have needed sponsors. Debts or obligations were undoubtedly called in and new ones created. The investment was so high that migration has been seen as the main vehicle of status competition in an otherwise rather undifferentiated earliest LBK context: in the absence of lavish graves or elaborate architecture, it seems any surplus at hand was used to found distant daughter settlements (Frirdich 2005.99-103).

A successful colonisation, in turn, would have resulted in considerable renown. This may have provided a strong motivation, particularly for those excluded from large inheritances, for instance by birth order. The colonisations of the Pacific, initially by Lapita groups and then reaching even the remotest islands of eastern Polynesia in the first millennium $\mathrm{AD}$, provide interesting parallels here. In the Lapita context, it is believed that the younger sons of chiefs and leaders, for whom there was little opportunity for wealth and glory at home, were instrumental in attracting followers and resources to drive forward the high-risk discovery and colonisation of new islands (Spriggs 2016.486-487). The benefit to them was obvious: rather than remain in a subordinate position at home, they could become the founders of new lineages elsewhere, as also re- corded for the later east Polynesian cases (Richards 2009), while their departure certainly also helped to protect more senior members from discontent and intrigue.

Alongside this political dimension, migration was intimately bound up with people's identity, both in their personal quest for greater standing and in terms of their worldview. The colonisation of new islands formed a large part of Pacific heroic mythology and group founding myths, so that by re-creating these journeys the travellers were perpetuating a fundamental aspect of their value system ( $R i$ chards 2009; 2010). The main point here is to appreciate the heady mix of pragmatic choice, personal opportunity and embeddedness in myth and history which characterised these ventures. Being so deeply engrained in the cultural fabric, colonisation formed a core value of Pacific societies at this time.

There are of course differences between this situation and the LBK, if only because the colonisation of uninhabited islands did not require interaction with prior inhabitants. Nevertheless, the models of patrilocality and lineage inheritance recently invoked for the LBK (Bogaard et al. 2011; Hedges et al. 2013, and see below) make it plausible or even likely that similar structural conditions promoting the migration of younger siblings were at work.

How long any daughter settlements, once established, would retain ties with their origin sites is an interesting topic for further research, as is the subsequent development of these sites. If it was important to cover large distances, then the earliest LBK sites close to one another, or even households on the same site, may have been founded by rival lineages or clans, eager to flaunt their successes to each other (Frirdich 2005.105). In this model, related households or sites would have established lines of solidarity across the landscape, with their closest allegiance to people far away. In contrast, Jörg Petrasch (2003.510-511) suggests that sites established early in the LBK sequence often developed into central places later on, forming a core around which smaller, perhaps dependent hamlets clustered, as has also been suggested for Austria (e.g., Pieler 2012.212-213). In this scenario, first arrivals in a new area would take on a leading role, forming what Anthony (1990.904) has termed 'apex families' to whom later newcomers owed deference. This would result in a pattern of clusters of closely linked sites, some of which may have stood out through particularly lavish material culture or buildings (Fig. 2). 
This has, for instance, been suggested for Nieder-Mörlen, an early LBK foundation in Hesse with traces of a possible ritual building (Lüning 2009.130-136), an impressive spectrum of figurines and other unusual artefacts, and pottery denoting longdistance ties (Schade-Lindig 2002; Schade-Lindig, Schade 2010). These alternatives - clusters versus chains of related sites - could be tested further in the future, and indeed elements of both scenarios could have coexisted. Here, I would like to focus on how this kind of prestige-driven migration would have influenced further events. New regions were colonised and new settlements established. And then what?

\section{What happens next}

\section{Scenario 1: we like it here}

There is still comparatively little debate surrounding the transition between the earliest LBK, during which initial large-scale migration took place, and the following LBK phases. Probably the most influential model is that developed by Christiane Frirdich (2003.546-547). She suggests that with increasing settlement density, migration became a less viable option3. Elders, who had previously sponsored migration events for younger generations and used this as the basis for social control, now lost their authority, as their promises could no longer be fulfilled. New ways of expressing prestige and social distinction had to be developed, and various avenues were tried out, including larger and architecturally more complex buildings and the deposition of wealth as grave goods in newly established cemeteries. For Ulrike Sommer (2001), too, the diversification of later LBK material culture is the result of a reduction in group migration events, after which material culture signalled belonging not at the culture-wide, but at the settlement and household level. A similar pattern of increasing regionalisation has also been recognised in other case studies of migration, for instance in the Pacific (Spriggs 2013).

There is much to commend this view. Although variations exist in earliest LBK material culture (Lenneis 2005; Strien 2009), the later LBK represents a

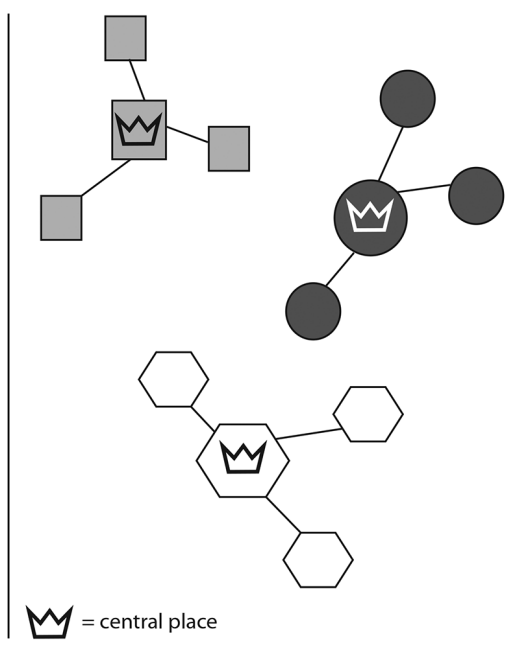

$M=$ central place

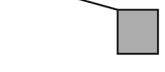
Fig. 2. Schematic representation of the two models of earliest LBK
settlement. Different shapes represent different lineages or clans. Left: Frirdich's model of linear solidarity; right: Petrasch's model of settlement clusters.

step-change in diversity in almost all areas of life. This happens at the same time as the landscape is progressively infilled, with site density increasing considerably in all regions.

The pervasive idea, then, is that once LBK groups reached a new location, they would settle and remain there, making the best of where they were. However, with increasing population density, the best would soon have turned sour. By the latest LBK, several regions, notably along the Rhine and in Hessen, may have seen a catastrophic collapse of some sort (e.g., Schade 2004.221-223; Zimmermann et al. 2005.33). It is still debated whether the reasons for this were primarily environmental (e.g., Strien, Gronenborn 2005) or social (Zeeb-Lanz 2009), but in either case it is implied that increasing territoriality, limiting access to land and resulting in exclusive definitions of identity, played a crucial role.

The importance of land inheritance may also be indicated by isotopic evidence. As Robert Hedges et alii (2013.367-369) have shown, there is an association between local isotopic signatures and males buried with polished stone adzes. This means that where an individual grew up had an impact on treatment at the time of death, a pattern which can plausibly be read as implying inheritance down the male line (Bentley et al. 2012; Hedges et al. 2013). That this inheritance involved land has been argued on the basis of evidence from Vaihingen, an LBK settlement in south-west Germany (Fig. 3). Here, as elsewhere,

3 This could also be related to a strong hunter-gatherer presence and/or a lack of appropriate soils and climatic conditions, limiting further expansion in certain directions (e.g., Lüning et al. 1989; Hartz et al. 2007.570; Thomas 1996). 
households and groups of households defined on the basis of material culture preferences tended to rebuild their houses in the same area of the site. In addition, detailed archaeobotanical studies have shown that some groups invested far more time in tending their crops than others. Looking at the weed assemblage, Amy Bogaard et alii (2011) identified neighbourhoods where inhabitants manured and weeded their crops, while others did not. This has been interpreted as high status groups having laid claim to the parcels of land closest to the site, while others had to make do with plots further away, which

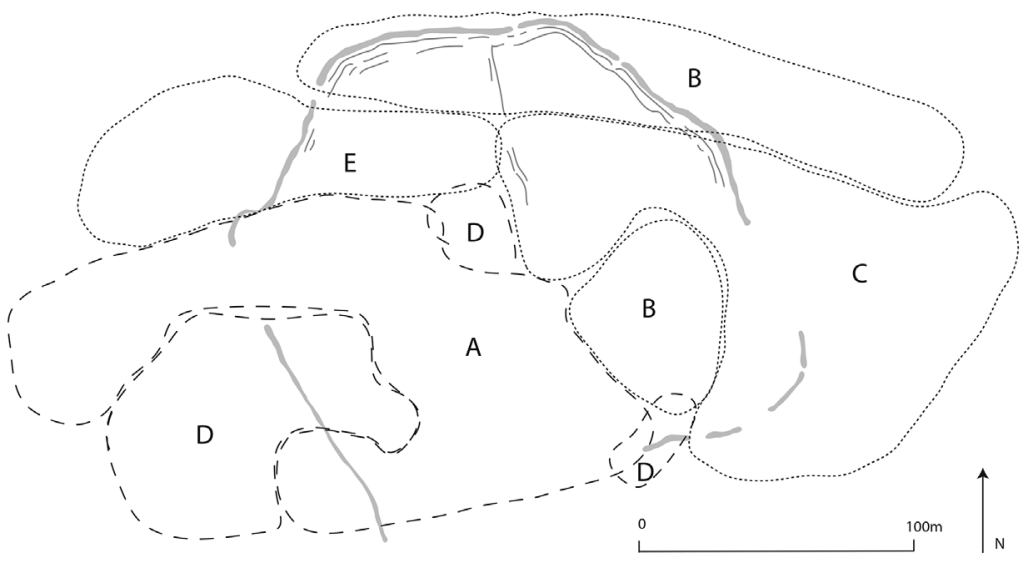

Fig. 3. Schematic outline of Vaihingen, showing the enclosure (gray) and the location of different 'clan groups' (A-E) defined on the basis of material culture preferences and economic choices. Dashed line: groups of the Middle Neckar tradition (who remain at Vaihingen); dotted line: groups of the Unterland-Kraichgau tradition (who eventually move away). Data after Bogaard et alii (2011) and Strien (2005). could not be tended as carefully. As a result, it is argued, those lower status groups eventually left the site (Bogaard et al. 2011), although this particular causal relationship is only one of several possibilities (see below).

In short, after the earliest LBK, effort was invested in putting down roots, and there is evidence for the importance of a person's origin and its link to land inheritance. Yet the question remains whether this behavioural pattern replaced migration quite so wholesale. Here, following Anthony (1997.29), I suggest that migration as a behaviour so strongly connected to status and prestige, and so bound up with group identity, did survive, albeit not unchanged. This could also help us to re-think some of the social models suggested for the LBK.

\section{Scenario 2: the grass is greener on the other side}

The evidence for the importance of genealogical ties in the LBK is convincing, but there has been an unhelpful tendency to see its link with land as the only means of obtaining social position. Yet things are rarely as clear-cut as that, and in day-to-day life the benefits and obligations derived from ties of descent from (male) ancestors would have to be balanced against other relationships, such as those structuring co-residence. Similarly, the standing of a household in relation to others could have been open to negotiation, shifting allegiances and political power plays.

For instance, in the Amazonian villages studied by Kaj Århem (2001), descent from known ancestors is an arena for status competition, particularly between men. This aspect is drawn upon in initiation rituals, but also in the daily consumption of valued items such as coca and snuff. Yet it coexists with practices centred on the sharing of food and drink between co-residents and across the village, again on both daily and ritual occasions. Here, status differences between individuals are denied and common identity is stressed through commensality, although people do keep an eye on whether everyone contributes as much as they can. In both spheres, then, there is potential for dissonance and conflict. In a case such as this, status and renown could be achieved in several ways. On the one hand, through contributing resources, dissipating tensions and stressing conviviality, a community of many residents could be held together, creating a site of some renown. However, if hierarchies within the group became unbearable or were overplayed, people in junior positions within the lineage could improve their lot by convincing others to form a breakaway settlement elsewhere, one in which their status would be increased. This kind of village fission is regularly observed ethnographically (e.g., also Bandy 2004; Barrier, Horsley 2014; Metcalf 2010.252). In such a case, archaeologically, we would expect to see communities of varying duration, whereby longerlasting ones could fluctuate in size over time.

Migration does not only happen when relations break down. In the Hopi Pueblos of the American Southwest, clans defined themselves by the chain of prior migrations in which they had been involved, generally relocating every two or three generations. In a given settlement, people with very different 
histories would thus live side by side, but these were never planned as long-lived communities (Bernardini 2005.7-8, 30). In the $15^{\text {th }}$ century $\mathrm{AD}$, villages in this arid region could reach impressive sizes and a greater degree of permanence, but nevertheless most shifted every few generations (Fowles 2001). Pragmatic reasons, such as soil exhaustion or resistance to Spanish colonisation, can be cited. However, to reduce Pueblo migration to these push factors alone misses an important aspect, namely the way migration was strongly interwoven in Hopi cultural values to the extent that it was considered a fundamental aspect of group identity. In the several decades in which a given Pueblo was settled, the importance of migration remained present through ritual dances, in myths and stories, and through the initiation rites of young men, who were sent to faraway locations, returning with exotic goods and knowledge of the wider landscape (Fowles 2001.49-52). Moving on was not a failure, but the normal course of existence, to the extent that the Hopi have been characterised as 'urbanized nomads' (Fox 1967.24), or as engaged in serial migration (Bernardini 2005.7-8). Simply because groups spent a few generations in one place does not mean that migration as a behaviour had become unimportant to them.

These case studies show that societies could exist in various 'modes' - stressing one or the other aspect of relationships, or being more or less settled at a given point in time. This presents people with alternative strategies that could be variously drawn upon. At a general level, migration, and the recombination of social groups in that process, thus remains an option even in many societies generally classified as sedentary, and these decisions were often taken at the level of clans, lineages or households. With these possibilities in mind, it is time to return to the evidence for continued migration in later LBK phases.

\section{Continued migration in the LBK}

In this section, I outline the role of migration events in later LBK phases, looking at three exemplary, but almost certainly not exhaustive, settings. The first is continued migration beyond established LBK settlement areas. This is archaeologically the most obvious, but may have been a viable choice particularly in those areas close to the shifting margins of the LBK. The second is shorter-distance migration within or at the edge of established LBK settlement re- gions, founding new sites and 'filling in' the landscape. This choice was most likely viable throughout the LBK distribution for several generations, although it was not universally taken up, remaining only one among several possible strategies. Finally, echoes of the migration process may also be visible in other cultural practices, such as house renewal, which were performed on virtually all LBK sites over the entire duration of this culture.

\section{Moving west: more colonisation}

While site density in areas already settled in the earliest LBK continued to increase, migration also continued to the east into what is now Romania, Moldova and Ukraine (e.g., Debiec, Saile 2015; Kotova 2003; Larina 2009) 4 , as well as westwards across the Rhine. LBK groups reached the Paris Basin probably by the end of the sixth millennium, and Normandy soon after (Billard et al. 2014.337-338). Yet what is notable is the changing role of material culture in this process. Earliest LBK material was similar over large distances, ostensibly to create a network of solidarity between widely spaced sites. In contrast, the newly established communities further west emerged at a time when this initial unity had begun to fragment, and they drove that process of diversification further. Thus, while the Paris Basin LBK can broadly be considered part of the Rubané du Nord-Ouest group (e.g., Lefranc 2007.27), there are also local peculiarities in pottery design and in burial customs, which are limited to settlement burials and focused on the provision of shell jewellery and ochre (Constantin et al. 2003; Hofmann, Bickle 2011; Jeunesse 2009).

One way to interpret these differences has been to stress the greater likelihood of hunter-gatherer involvement in these western areas, introducing behaviours which transcended or challenged LBK norms (e.g., Jeunesse 2009). However, an alternative explanation is possible. At least in certain cases, emerging regional pottery groups within the LBK correlate with other aspects of material culture and behaviour and have been interpreted as ethnic boundaries (e.g., Pechtl 2016). People may have chosen to define a group identity based on shared ancestry, or on a shared origin and history, and to express this by distinguishing themselves from their neighbours. The stylistic innovations found in the Paris Basin could be part of such a process of ethnogenesis. For colonists perhaps drawn from several parent communities or lineages, material culture which resem-

4 These areas will not be treated in greater depth here, as large-scale excavations are still rare. 
bled no one existing tradition too closely would have been well suited to signal a new social formation, while the migration movement itself could have provided a shared experience as the basis for a new group identity5.

Overall, then, the link between an end to migration and the diversification of material culture, as suggested by Frirdich (2003) and others, is only part of the story. As long as the LBK lasted, migration never really stopped entirely. What appears to have altered is how groups saw their allegiance once migration was over, and the role material culture played in these transformations. In the earliest LBK, widespread similarity in all aspects of material culture ensured that people could find their way around whichever community they were currently in, creating a far-flung, island-like pattern of similar sites where people made similar choices. By the late LBK, this unity had disappeared, and migration may have been one more means by which to differentiate oneself from others at the group level.

In future, it will be interesting to think further about whether these changing aftermaths of migration, from similarity to differentiation, went hand in hand with a changing organisational backdrop. For instance, are we witnessing a shift from migrations sponsored by elders to migrations of discontent? And what does this say about the role of lineages or clans, as opposed to territorially defined groups? For now, I would like to turn to evidence that even away from the LBK's ever-shifting western and eastern frontiers, migration remained a viable choice.

\section{Moving around, not necessarily far}

The continued importance of migration even within established LBK settlement regions goes well beyond seasonal rounds of mobility or one-off residential changes by individuals. Households or larger sections of communities could also take the decision to relocate. We have already encountered the idea that at Vaihingen, disadvantaged social groups were pushed out of a settlement in which they were only ever accorded marginal lands. However, seen from a perspective in which migration may not be equivalent to failure, and bearing the example of the Hopi Pueblos in mind, one could also develop another explanation. The suggested neighbourhoods or clan groups are not only distinct from each other in terms of weed assemblages, but also concerning the animal bone spectrum. According to archaeozoological evidence (Schäfer, Arbogast forthcoming) and isotopic measurements on cattle teeth (Knipper forthcoming), cattle dominate across the site, but the households which invested more time in maintaining their plots grazed their animals in uplands and river valleys, and also kept comparatively more pigs, probably closer to home. In contrast, groups with less well maintained plots in turn grazed their animals on loess and kept more of the potentially more mobile sheep and goats. This fits with the existing evidence for diversity in economic choices within LBK communities (e.g., Hachem 2000; 2011). As

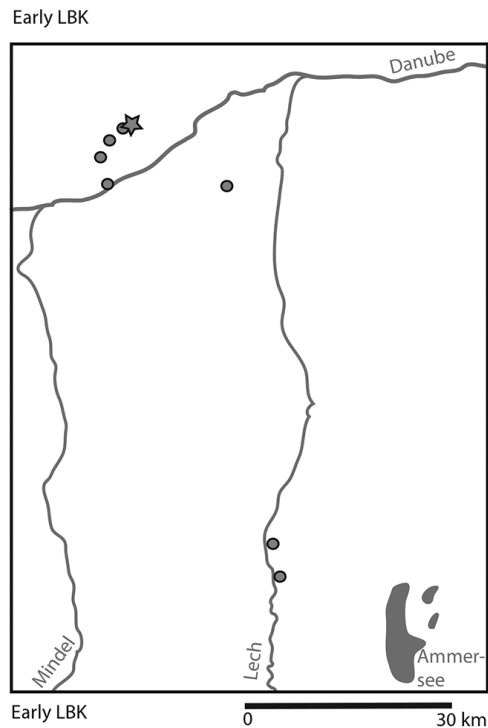
Mid LBK

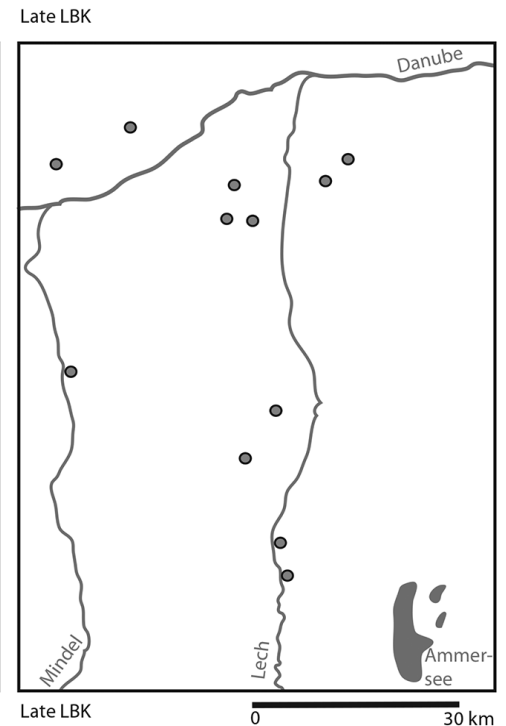

Fig. 4. Phases of colonisation of the Lech valley. Only dated LBK sites are shown. The star symbol denotes the only site also settled in the earliest LBK. After Pechtl (2011.Fig. 2).

5 This is not to deny that foragers could have participated in these events. However, as the observed material culture changes are very strongly rooted in the LBK, forager involvement is unlikely to be the sole, or indeed the main, mechanism active here. 


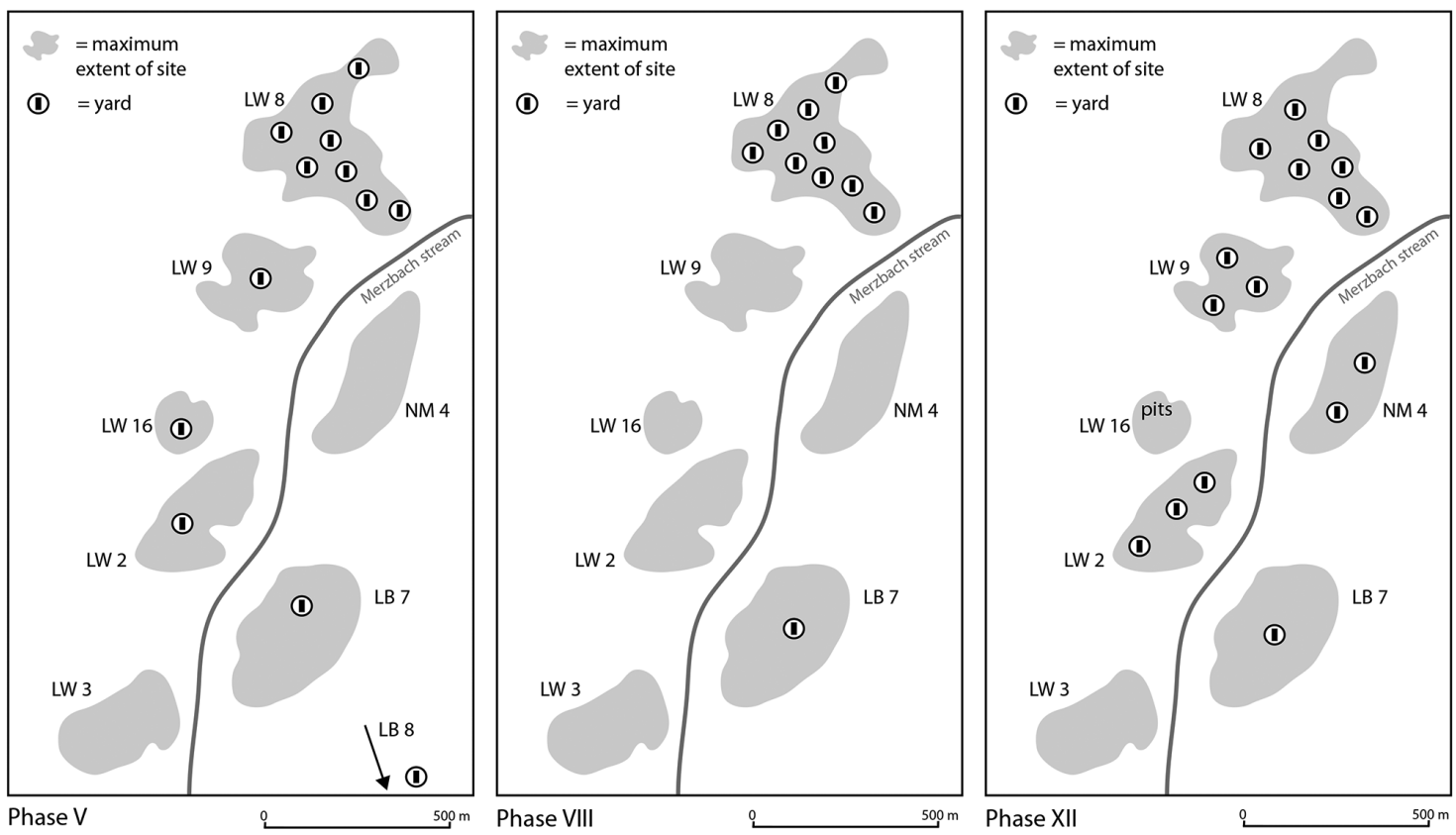

Fig. 5. Number of yards on sites in the middle Merzbach valley in phases V, VIII and XII. Location of sites within yards is schematic only and does not correspond to their real position. LW Langweiler; LB Laurenzberg; NM Niedermerz. After data and base map in Stehli (1994), with corrections by Münch (2009).

wealth on the hoof, cattle in particular could have provided an alternative way to gain social standing (e.g., Parker Pearson 2000; Russell 1998; Whittle 2003.80), meaning that status need not relate exclusively to controlling agricultural land.

This importance accorded to cattle keeping, in conjunction with a less important role for pigs, could have enabled households to remain more mobile in the medium and longer term. Settling in any one place for longer than a few generations and investing in enduring plots may simply not have been high on the agenda for these groups. Instead, they kept different choices open and remained able to react to promising opportunities pulling them along a new path. In this case, community fissioning every few generations could have been the rule rather than the exception.

Indeed, looking closer at situations with detailed evidence for settlement sequences, there is a lot of fluctuation in settlement biographies. Frequently, it appears that people took the first possible opportunity to move into a new area. For instance, in his detailed study of settlement patterns in the Lech valley, south of the Danube in western Bavaria, Joachim Pechtl (2011) has shown that sites were repeatedly established closer to the Alpine foreland in periods of favourable climatic conditions, and abandoned when they became untenable (Fig. 4). It is tempting to see the origins of these Lech valley settlers in one of the larger sites with early foundation dates along the Danube, although this will need to be verified by further directed study 6 . Irrespective of their origin points, these people clearly were strongly motivated to establish new sites, rather than expanding existing ones.

The Merzbach valley in the Rhineland provides another example and is particularly interesting because several adjacent sites could be fully excavated, giving a picture at the level of the settlement cell. The definition of phases (or 'house generations') has been criticised in its details and in the rigidity of its application (e.g., Rück 2009; Schwerdtner 2007), but broad patterns are reliable. One can observe probable expansion out of the founding settlement, Langweiler 8, in some phases (Tab. 1; Fig. 5; Stehli 1994), when sites in the immediate vicinity were established, but Langweiler 8 remained the same size.

However, in phase VIII, most of the smaller sites are again abandoned, and there are gaps at individual sites during other phases. Where these households moved to is another question, but continued migration beyond the Merzbach valley is a likely scenario. Population peaks in later phases are also largely reached, because the smaller sites, rather than Lang-

6 A project led by Joachim Pechtl is in progress. 
weiler 8 , are growing. Interestingly, while Langweiler 9 had initially shown strong links to Langweiler 8 in pottery decoration, this is no longer the case after the phase VIII hiatus (Frirdich 1994.356). If pottery decoration is a reliable indicator for close connections at the household and lineage level (and this is admittedly a big 'if'), then this would suggest that the re-settlement of Langweiler 9 was not undertaken by the same social group that first established the site, further stressing the degree of fluidity in settlement choice.

Fluctuation can also be traced in settlement sequences on individual yards. The partially excavated settlement of Stephansposching (Lower Bavaria) has been tentatively divided into ten settlement phases, using a combination of ceramic sequencing and house overlaps (Pechtl 2009.502-504). After an initial three generations in which the number of yards increases quickly, there is a period of stability between phases IV and VII, followed by relatively rapid decline (Fig. 6). However, a more detailed look at individual phases reveals an undercurrent of fluctuation even in some of the 'stable' phases, as some yards are abandoned while others are established anew. Several caveats remain, particularly the fact that the site is incompletely excavated and the phasing method used tends to overestimate house numbers in the middle phases, while underestimating them at the start and end (Pechtl 2009.492). Nevertheless, it is clear that there was a certain level of coming and going, in which some households were attracted to Stephansposching, while others preferred to move on.

Certainly, then, there was enough flexibility in any system of land tenure to allow for the departure of households, and perhaps even for their re-integration elsewhere, especially if there were lineage or other pre-existing connections. This is now visible in several regions of LBK settlement, and is likely to become more evident as detailed site narratives increase 7 . Yet in all these cases, it seems that several generations of settling in one place separated instan- ces of migration of greater or smaller parts of the population. On the one hand, this indicates that abandonment of a given site (much like establishment) was sometimes a phased process of some duration, with the decision to leave taken by small groups of households. On the other hand, it begs the question of whether, as in the Hopi case above, we can identify mechanisms which would have acted to keep migration salient as a valued cultural choice, even over longer episodes in which a given social group stayed put.

\section{Memories of migration}

The re-creation of ancestral journeys in ritual and myth could be a mechanism here, as it is for the Hopi (Fowles 2012.53). Yet while long-term absences by youngsters could potentially be tracked isotopically, in detail it remains difficult to differentiate between scenarios such as herding, stays with foster families or as migrant labour, or indeed long-distance exploratory journeys (e.g., Gronenborn 2010. 566-567; Knipper 2011.348).

A more ubiquitous and longer-lasting practice is the rebuilding of LBK houses in every new generation. Longhouses could technically have been used for many decades (Lenneis, Trebsche 2013; Schmidt et al. 2005), but this suggestion has not yet been backed up by a plausible phasing framework. The ebb and flow of houses, and in some cases the over-

\footnotetext{
7 Also, there is a trend to assign houses undated by pottery to phases in such a way that gaps in the overall settlement sequence are minimised (e.g., Boelicke et al. 1988.900-901; Pechtl 2009.496). As such, fluctuations in house numbers are very likely underestimated.
} 
lapping of house plans on more densely settled sites, suggest instead that that the model of generational replacement, while perhaps sometimes too rigidly applied, holds true in general. This means that people frequently rebuilt their longhouses not because these had become structurally unsound, but for social reasons. In this context, the resources and labour that needed to be invested in a new longhouse were vehicles for displaying wealth and connections, competing for status in a potentially fluid social situation (e.g.,

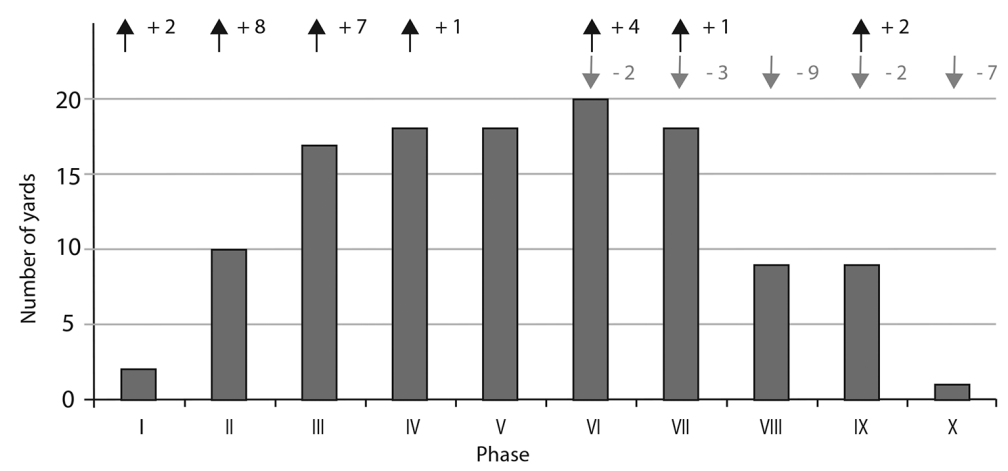

Fig. 6. Fluctuation of settlement size at Stephansposching. For each phase, arrows pointing up show the number of new yards established; arrows pointing down show the number of yards abandoned. Generated from data in Pechtl (2009.502-504).
Hofmann 2012; 2013). Yet in addition, and to further bolster status claims, re-establishing a house, even if just some tens of metres away, can also be read as a re-creation of the group's first settlement at a given site, most likely hedged about with origin myths or heroic tales.

Most interesting in this respect are the so-called 'founding buildings' now excavated at several western LBK sites, particularly in Belgium. Here, the chronologically earliest house to be identified, generally a quite substantial building, did not form the origin of a later yard, i.e. of an area in which houses were replaced in following generations. Instead, this building remained isolated, and later dwellings, this time grouped into several yards, were established some distance away: within the enclosure at Darion, or 50 to $130 \mathrm{~m}$ away at Fexhe and Remicourt, for example (Bosquet, Golitko 2012; Bosquet et al. 1998). Occasionally, founding buildings are associated with peculiarities in material culture such as nonLBK ceramics (Limburg and other traditions) at Fexhe (Bosquet, Golitko 2012. 94). These sorts of buildings, then, could have formed a kind of collective origin point for the whole community, a visible reminder of the migration of the founders to a new site, re-created in a small way by all successive house-building generations. Yet even where such 'founding buildings' do not exist, new houses seemingly referenced earlier structures. As Jens Lüning (2005) has argued, this happened either by forming lines of successive buildings ('father principle'), or by referencing their predecessor's predecessor ('grandfather principle'; Fig. 7). In either case, there was evidently a desire to express one's connection to a genealogical line, even while re-locating the longhouse.

Although these suggestions remain speculative, they outline how migration could have remained a salient and actively performed cultural behaviour even in longer periods in which there was no larger-scale or longer-distance migration at all. While commemorating and re-enacting migration was very likely not the only function these practices fulfilled, tying migration to behaviours which were also socially relevant in other ways, such as status competition, reaffirmed it as a valued cultural choice, experienced at the personal scale of household and community politics.

\section{Conclusions and outlook}

In sum, there are indications that LBK society witnessed group migration even beyond the earliest phases. At a macroscale, the continued importance of colonisation remains undisputed. Taking this as a starting point, this paper has shown ways in which such large-scale undertakings were embedded in the LBK cultural fabric as a whole by being performed and re-created as viable cultural choices at the level
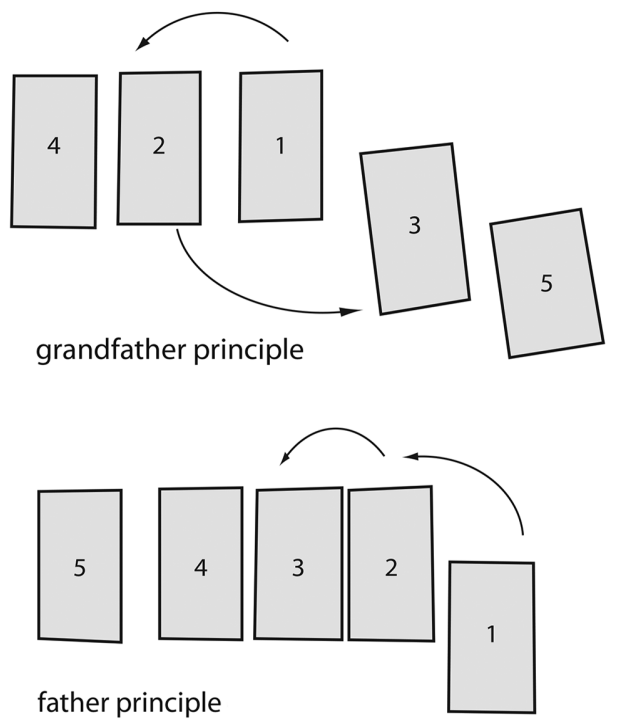

Fig. 7. Alternative modes of house replacement on LBK yards. After Lüning (2005.Figs. 59-60). 
of communities, households and individuals. The decision to move could be taken at several levels, from groups of yards at Vaihingen and along the Lech to sometimes single households at Stephansposching. Migration was most likely connected to a hope for better opportunities elsewhere, as well as to a group's sense of a shared way of life. It could have functioned as a counter-balance to a social logic of patrilocality and land inheritance, so far stressed in most archaeological accounts, and may have been backed by economic choices enabling a greater degree of mobility and group migration. In this way, according a key role to migration suggests new, plausible connections between many different spheres of life, involving economic choices, status display and even founding myths. It is at these levels that the foundations for longer-range colonisation ventures were laid. The changing character of these migrations, in terms of possible motivations, the decision-making groups involved and the relationship to (ethnic) identity, must be investigated further in the future.

Migration was not of course the only possible option. Indeed, the basic make-up of LBK social structure seems to have been sufficiently flexible to accommodate a wide range of settlement patterns. In some instances, mechanisms to reduce community fissioning were apparently found, creating sites with greater settlement densities. For instance, preliminary research at Vráble-Vel'ké Lehemby suggests that models of settlement organisation changed over time, and that a large community of several tens of contemporary houses could have existed in some phases (Furholt et al. 2014.250-254). Similarly, it has been suggested that the limited opportunities for migration in the Alföld LBK led to alternative strategies, notably the faster establishment of social stratification (Domboróczki 2009.122-123).

Whether migration was considered a viable choice would hence have differed depending on where and when one asked this question. This is also the case for the consequences of migration. In the earliest LBK, it resulted in long-distance networks, while later on more effort went into stressing the creation of boundaries. This process of ethnogenesis, i.e. the creation of new identity groups based on a belief of shared descent or history, and defined in opposition to others, will not be amenable to biomolecular study. Especially in the later LBK, when relocations may have taken place within established settlement regions, aDNA (and indeed isotopes) will be a poor guide for tracing the precise origins of migrants. In- creasing territoriality as expressed in material culture boundaries took place between genetically largely identical populations, most of whom had grown up on loess soils. For these instances, then, defining migrations remains as challenging as it has ever been: reasons, group size and composition, distances travelled and so on will have to be reconstructed largely on the basis of detailed archaeological work.

However, in spite of these difficulties, the problem merits close attention. If the earliest LBK expansion left its traces not just on the distribution maps of archaeologists, but also in the attitudes and behaviours of later LBK communities, then the migration of larger social groups must be added to our research agendas alongside the identification of tethered mobility and individual relocation. This contributes to the impression that the LBK, in spite of its monumental wooden longhouses, was far from settled, with mobility and migration possible, and practised, at various scales. This should not be read as sign of a 'Mesolithic' heritage. Instead, such behaviours were specifically Neolithic, carried out for new kinds of reasons (such as personal renown) and embedded in an entirely new set of social circumstances. It was never too late to move on. 


\section{References}

Andresen M. 2004. Studien zur Geschichte und Methodik der archäologischen Migrationsforschung. Waxmann. Münster.

Anthony D. W. 1990. Migration in archaeology: the baby and the bathwater. American Anthropologist 92: 895914.

1997. Prehistoric migration as social process. In J. Chapman, H. Hamerow (eds.), Migrations and invasions in archaeological explanation. British Archaeological Records IS 664. Archaeopress. Oxford: 21-32.

Århem K. 2001. From longhouse to village: structure and change in the Colombian Amazon. In L. Rival, N. Whitehead (eds.), Beyond the visible and the material. The Amerindianization of society in the work of Peter Rivière. Oxford University Press. Oxford: 123-155.

Bandy M. S. 2004. Fissioning, scalar stress and social evolution in early village societies. American Anthropologist 106: 322-333.

Bánffy E. 2004. The $6^{\text {th }}$ millennium BC boundary in western Transdanubia and its role in the central European Neolithic transition. (The Szentgyörgyvölgy-Pityerdomb settlement). Archaeological Institute of the Hungarian Academy of Sciences. Budapest.

Barrier C. R., Horsley T. J. 2014. Shifting communities: demographic profiles of early village population growth and decline in the central American Bottom. American Antiquity 79: 295-313.

Bentley R. A., Krause R., Price T. D. and Kaufmann B. 2003. Human mobility at the early Neolithic settlement of Vaihingen, Germany: evidence from strontium isotope analysis. Archaeometry 45: 481-496.

Bentley R. A. and 14 co-authors. 2012. Community differentiation and kinship among Europe's first farmers. Proceedings of the National Academy of Sciences of the USA 109: 9326-9330.

Billard C., Bostyn F., Hamon C. and Meunier K. 2014. Synthèse. In C. Billard, F. Bostyn, C. Hamon and K. Meunier (eds.), L'habitat du Néolithique ancien de Colombelles "Le Lazzaro" (Calvados). Société Préhistorique Française. Paris: 333-342.

Bocquet-Appel J.-P. 2008. Explaining the Neolithic demographic transition. In J.-P. Bocquet-Appel, O. Bar-Yosef (eds.), The Neolithic demographic transition and its consequences. Springer. New York: 35-55.

Boelicke U., von Brandt D., Lüning J., Stehli P. and Zimmermann A. 1988. Struktur und Entwicklung des Sied- lungsplatzes. In U. Boelicke, D. von Brandt, J. Lüning, P. Stehli and A. Zimmermann (eds.), Der bandkeramische Siedlungsplatz Langweiler 8, Gemeinde Aldenhoven, Kreis Düren. Rheinland-Verlag. Köln: 891-931.

Bogaard A., Krause R. and Strien H.-C. 2011. Towards a social geography of cultivation and plant use in an early farming community: Vaihingen an der Enz, south-west Germany. Antiquity 85: 395-416.

Bogucki P. 1988. Forest farmers and stockherders. Early agriculture and its consequences in north-central Europe. Cambridge University Press. Cambridge.

Bollongino R., Nehlich 0., Richards M. P., Orschiedt J., Thomas M. G., Sell C., Fajkošová Z., Powell A. and Burger J. 2013. 2000 years of parallel societies in Stone Age central Europe. Science 342: 479-481.

Bosquet D., Golitko M. 2012. Highlighting and characterising the pioneer phase of the Hesbayen Linear Pottery Culture (Liège province, Belgium). In R. Smolnik (ed.), Siedlungsstruktur und Kulturwandel in der Bandkeramik. Beiträge der internationalen Tagung "Neue Fragen zur Bandkeramik oder alles beim Alten?!”, Leipzig 23.-24. September 2010. Landesamt für Archäologie Sachsen. Leipzig: 91-106.

Bosquet D., Fock H., Goffioul C. and Preud'Homme D. 1998. Le site rubané de Fexhe-le-Haut-Clocher - Podrî l'Cortri: résultats des fouilles. Notae Praehistoricae 18: 131-140.

Brandt G. and 17 co-authors. 2013. Ancient DNA reveals key stages in the formation of central European mitochondrial genetic diversity. Science 342: 257-261.

Burmeister S. 2000. Archaeology and migration: approaches to an archaeological proof of migration. Current Anthropology 41: 539-567.

Chapman J., Hamerow H. 1997. On the move again: migrations and invasions in archaeological explanation. In J. Chapman, H. Hamerow (eds.), Migrations and invasions in archaeological explanation. Archaeopress. 0xford: $1-10$.

Childe V. G. 1929. The Damube in prehistory. Clarendon. Oxford.

Constantin C., Farruggia J.P., Bonnardin S., Guichard Y. and Sidéra I. 2003. Les tombes rubanées de la vallée de l'Aisne. Présentation. In P. Chambon and J. Leclerc (eds.), Les pratiques funéraires Néolithiques avant 3500 av. J.C. en France et dans les régions limitrophes. Editions Errance. Paris: 55-63. 
Dębiec M., Saile T. 2015. Zu den östlichsten Siedlungen der frühen Bandkeramik. Prähistorische Zeitschrift 90: 1-19.

Domboróczki L. 2009. Settlement structures of the Alföld Linear Pottery Culture (ALPC) in Heves county (north-eastern Hungary): development models and historical reconstructions on micro, meso and macro levels. In J. K. Kozłowski (ed.), Interactions between different models of Neolithization north of the central European agro-ecological barrier. Polska Akademia Umiejętnośi. Kraków: 75-127.

Ebersbach R. 2002. Von Bauern und Rindern. Eine Ökosystemanalyse zur Bedeutung der Rinderhaltung in bäuerlichen Gesellschaften als Grundlage zur Modellbildung im Neolithikum. Schwabe. Basel.

Fowles S. M. 2011. Movement and the unsettling of the Pueblos. In G. S. Cabana, J. J. Clark (eds.), Rethinking anthropological perspectives on migration. University of Florida Press. Gainesville: 45-67.

Fox R. 1967. The Keresan bridge. A problem in Pueblo ethnology. Athlone Press. London.

Frirdich C. 1994. Kulturgeschichtliche Betrachtungen zur Bandkeramik im Merzbachtal. In J. Lüning, P. Stehli (eds.), Die Bandkeramik im Merzbachtal auf der Aldenhovener Platte. Rheinland-Verlag. Köln: 207-393.

2003. Strukturen im Wandel. Ein bandkeramisches Gräberfeld entsteht. In J. Eckert, U. Eisenhauer and A. Zimmermann (eds.), Archäologische Perspektiven. Analysen und Interpretationen im Wandel. Festschrift für Jens Lüning zum 65. Geburtstag. Marie Leidorf. Rahden: 545-559.

2005. Struktur und Dynamik der bandkeramischen Landnahme. In J. Lüning, C. Frirdich and A. Zimmermann (eds.), Die Bandkeramik im 21. Jahrhundert. Symposium in der Abtei Brauweiler bei Köln vom 16.9.-19.9.2002. Marie Leidorf. Rahden: 81-109.

Furholt M., Bátora J., Cheben I., Kroll H., Rassmann K. and Tóth P. 2014. Vráble-Vel'ké Lehemby: Eine Siedlungsgruppe der Linearkeramik in der Südwestslowakei. Vorbericht über die Untersuchungen der Jahre 2010 und 2012 und Deutungsansätze. Slovenská Archeológia 62: 227-266.

Gamba C. and 16 co-authors. 2014. Genome flux and stasis in a five millennium transect of European prehistory. Nature Communications 5. doi:10.1038/ncomms6257.

Gronenborn D. 1999. A variation on a basic theme: the transition to farming in southern central Europe. Journal of World Prehistory 13: 123-210.
2006. Climate change and socio-political crises: some cases from Neolithic central Europe. Journal of Conflict Archaeology 2: 13-32.

2010. Fernkontakte aus dem nördlichen Europa während der Bandkeramischen Kultur. In J. Suteková, P. Pavúk, P. Kalábková and B. Kovár (eds.), Panta Rhei. Studies in chronology and cultural development of south-eastern and central Europe in earlier prehistory presented to Juraj Pavúk on the occasion of his $7^{\text {th }}$ birthday. Comenius University. Bratislava: 561-574.

Haak W. and 17 co-authors. 2010. Ancient DNA from European early Neolithic farmers reveals their Near Eastern affinities. PLoS Biology 8(11): 1000536.

Hachem L. 2000. New observations on the Bandkeramik house and social organisation. Antiquity 74: 308-312.

2011. Le site néolithique de Cuiry-lès-Chaudardes I. De l'analyse de la faune à la structuration sociale. Marie Leidorf. Rahden.

Hannam K., Sheller M. and Urry J. 2006. Editorial: mobilities, immobilities and moorings. Mobilities 1: 1-22.

Härke H. 1998. Archaeologists and migrations: a problem of attitude? Current Anthropology 39: 19-46.

Hartz S., Lübke H. and Terberger T. 2007. From fish and seal to sheep and cattle: new research into the process of Neolithisation in northern Germany. In A. Whittle, V. Cummings (eds.), Going over: the Mesolithic-Neolithic transition in north-west Europe. Oxford University Press. Oxford: 567-594.

Hedges R. E. M., Bentley R. A., Bickle P., Cullen P., Dale, C., Fibiger L., Hamilton J., Hofmann D., Nowell G. and Whittle A. 2013. The supra-regional perspective. In P. Bickle, A. Whittle (eds.), The first farmers of central Europe. Diversity in LBK lifeways. Oxbow. Oxford: 343384.

Hofmann D. 2012. Bodies, houses and status in the western Linearbandkeramik. In T. Kienlin, A. Zimmermann (eds.), Beyond elites. Alternatives to hierarchical systems in modelling social formations. Habelt. Bonn: 183-196.

2013. Narrating the house. The transformation of longhouses in early Neolithic Europe. In A. Chadwick, C. Gibson (eds.), Memory, myth and long-term landscape inhabitation. Oxbow. 0xford: 32-54.

2015. What have genetics ever done for us? The implications of aDNA data for interpreting identity in early Neolithic central Europe. European Journal of Archaeology 18: 454-476. 
Hofmann D., Bickle P. 2011. Culture, tradition and the settlement burials of the Linearbandkeramik (LBK) culture. In B. Roberts, M. Vander Linden (eds.), Investigating archaeological cultures: material culture variability and transmission. Springer. New York: 183-200.

Hu D. 2013. Approaches to the archaeology of ethnogenesis: past and emergent perspectives. Journal of Archaeological Research 21: 371-402.

Jeunesse C. 2009. Le front de colonisation occidental (entre Rhin et Seine) et l'identité rubanée. In J. K. Kozłowski (ed.), Interactions between different models of NeOlithization north of the central European agro-ecological barrier. Polska Akademia Umiejętności. Krakow: 151-176.

Kalicz N. 2010. An der Grenze "zweier Welten" - Transdanubien (Ungarn) im Frühneolithikum. In D. Gronenborn, J. Petrasch (eds.), Die Neolithisierung Mitteleuropas - The spread of the Neolithic to central Europe. Verlag des Römisch-Germanischen Zentralmuseums. Mainz: 235-254.

Kaufmann V., Bergmann M. M. and Joye D. 2004. Motility: mobility as capital. International Journal of Urban and Regional Research 28: 745-756.

Knipper C. 2011. Die räumliche Organisation der linearbandkeramischen Rinderhaltung: naturwissenschaftliche und archäologische Untersuchungen. British Archaeological Reports IS 2305. Archaeopress. Oxford.

forthcoming. Strontium isotope analysis on land use and the mobility of humans and animals. Contribution in A. Bogaard, R. Krause (eds.), The Bandkeramik settlement of Vaihingen an der Enz, Kreis Ludwigsburg (Baden-Württemberg): an interim report on post-excavation analyses. Germania.

Kotova N. S. 2003. Neolithization in Ukraine. British Archaeological Reports IS 1109. Archaeopress. Oxford.

Larina 0. 2009. The extreme eastern periphery of the Linearbandkeramik: the landscape and geographical contexts. In D. Hofmann, P. Bickle (eds.), Creating communities. New advances in central European Neolithic research. Oxbow. Oxford: 50-70.

Lefranc P. 2007. La céramique du Rubané en Alsace. Contribution à l'étude des groupes régionaux du Néolithique ancien dans la plaine du Rhin supérieur. Université Marc Bloch. Strasbourg.

Lenneis E. 2005. Die "Einheitlichkeit" der frühen Bandkeramik - Forschungsstand oder Realität? In J. Lüning, C. Frirdich and A. Zimmermann (eds.), Die Bandkeramik im 21. Jahrhundert. Symposium in der Abtei Brauweiler bei Köln vom 16.9.-19.9.2002. Marie Leidorf. Rahden: 75-79.
Lenneis E., Trebsche P. 2013. Die Dokumentation des nachgebauten linearbandkeramischen Langhauses von 1964 im Urgeschichtemuseum Asparn an der Zaya - Ein Beitrag zur Diskussion der möglichen Lebensdauer. In E. Lauermann (ed.), Das "jungsteinzeitliche" Langhaus in Asparn an der Zaya. Niederösterreichisches Institut für Landeskunde. St. Pölten: 87-145.

Lüning J. 1988. Frühe Bauern in Mitteleuropa im 6. und 5. Jahrtausend v. Chr. Jahrbuch des Römisch-Germanischen Zentralmuseums Mainz 35: 27-93.

2005. Bandkeramische Hofplätze und absolute Chronologie der Bandkeramik. In J. Lüning, C. Frirdich and A. Zimmermann (eds.), Die Bandkeramik im 21. Jahrhundert. Symposium in der Abtei Brawweiler bei Köln vom 16.9.-19.9.2002. Marie Leidorf. Rahden: 49-74.

2009. Bandkeramische Kultanlagen. In A. Zeeb-Lanz (ed.), Krisen-Kulturwandel-Kontinuitäten. Zum Ende der Bandkeramik in Mitteleuropa. Beiträge der internationalen Tagung in Herxheim bei Landau (Pfalz) from 14.-17.06.2007. Marie Leidorf. Rahden: 129-190.

Lüning J., Kloos U. and Albert S. 1989. Westliche Nachbarn der bandkeramischen Kultur: La Hoguette und Limburg. Germania 67: 355-420.

Mathieson I. and 37 co-authors. 2015. Genome-wide patterns of selection in 230 ancient Eurasians. Nature 528: 499-503.

Metcalf P. 2010. The life of the longhouse: an archaeology of ethnicity. Cambridge University Press. Cambridge.

Midgley M. 2005. The monumental cemeteries of prehistoric Europe. Tempus. Stroud.

Münch U. 2009. Zur Siedlungsstruktur der Flombornzeit auf der Aldenhovener Platte. In A. Zimmermann (ed.), Studien zum Alt- und Mittelneolithikum im rheinischen Braunkohlerevier. Marie Leidorf. Rahden: 1-101.

Parker Pearson M. 2000. Eating money: a study in the ethnoarchaeology of food. Archaeological Dialogues 7: 217-232.

Pechtl J. 2009. Stephansposching und sein Umfeld. Studien zum Altneolithikum im bayerischen Donauraum. Unpublished PhD thesis. Heidelberg University. Heidelberg.

2011. Am Rande des Machbaren: zwei gescheiterte linienbandkeramische Kolonisationswellen im Lechtal. In T. Doppler, B. Ramminger and D. Schimmelpfennig (eds.), Grenzen und Grenzräume? Beispiele aus Neolithikum und Bronzezeit. Welt und Erde. KerpenLoogh: 37-51. 
2016. From distribution maps to 'ethnic' diversity within the southern Bavarian LBK. In L. Amkreutz, F. Haack, D. Hofmann and I. van Wijk (eds.), Something out of the ordinary? Interpreting diversity in the Early Neolithic Linearbandkeramik and beyond. Cambridge Scholars Publishing. Newcastle: 283-311.

Petrasch J. 2003. Zentrale Orte in der Bandkeramik? In J. Eckert, U. Eisenhauer and A. Zimmermann (eds.), $A r$ chäologische Perspektiven. Analysen und Interpretationen im Wandel. Festschrift für Jens Lüning zum 65. Geburtstag. Marie Leidorf. Rahden: 505-513.

Pieler F. 2010. Die Bandkeramik im Horner Becken (Niederösterreich). Studien zur Struktur einer frühneolithischen Siedlungskammer. Habelt. Bonn.

Richards C. 2009. The substance of Polynesian voyaging. World Archaeology 40: 206-223.

2010. On the road of the winds: journeying across the blue waters of the Pacific, and along the roads of Rapa Nui. In H. Martinsson-Wallin, P. Wallin (eds.), The Gotland papers. Selected papers from the VII international conference on Easter Island and the Pacific: migration, identity and cultural heritage. Gotland University Press. Gotland: 155-166.

Rück 0. 2009. New aspects and models for Bandkeramik settlement research. In D. Hofmann, P. Bickle (eds.), Creating communities. New advances in central European Neolithic research. 0xbow. Oxford: 159-185.

Russell N. 1998. Cattle as wealth in Neolithic Europe: where's the beef? In D. W. Bailey (ed.), The archaeology of value. Essays on prestige and the process of valuation. British Archaeological Reports IS 730. Archaeopress. Oxford: $42-54$.

Schade C. 2004. Die Besiedlungsgeschichte der Bandkeramik in der Mörlener Bucht/Wetterau. Zentralität und Peripherie, Haupt- und Nebenorte, Siedlungsverbände. Habelt. Bonn.

Schade-Lindig S. 2002. Idol- und Sonderfunde der bandkeramischen Siedlung von Bad Nauheim - Nieder-Mörlen "Auf dem Hempler" (Wetteraukreis). Germania 80: 47114.

Schade-Lindig S., Schade C. 2010. Woher kommt Flomborn? Keramikimporte und Nachahmungen in der bandkeramischen Siedlung Bad Nauheim - Nieder-Mörlen "Auf dem Hempler". In D. Gronenborn, J. Petrasch (eds.), Die Neolithisierung Mitteleuropas - The spread of the Neolithic to central Europe. Verlag des Römisch-Germanischen Zentralmuseums. Mainz: 461-474.

Schäfer M., Arbogast R.-M. forthcoming. Faunal remains from the LBK settlement of Vaihingen an der Enz. In A.
Bogaard, R. Krause (eds.), The Bandkeramik settlement of Vaihingen an der Enz, Kreis Ludwigsburg (Baden-Württemberg): an interim report on post-excavation analyses. Germania.

Schmidt B., Gruhle W., Rück 0. and Freckmann K. 2005. Zur Dauerhaftigkeit bandkeramischer Häuser im Rheinland (5300-4950 v. Chr.) - eine Interpretation dendrochronologischer und bauhistorischer Befunde. In D. Gronenborn (ed.), Klimaveränderung und Kulturwandel in neolithischen Gesellschaften Mitteleuropas, 67002200 v. Chr. Verlag des Römisch-Germanischen Zentralmuseums. Mainz: 151-170.

Schwerdtner G. 2007. Siedlungsgruben - Seriation und Zufall. Archäologisches Korrespondenzblatt 37: 189-205.

Siegmund F. 2014. Kulturen, Technokomplexe, Völker und Identitätsgruppen: eine Skizze der archäologischen Diskussion. Archäologische Informationen 37: 53-65.

Sommer U. 2001. 'Hear the instructions of thy father, and forsake not the law of thy mother'. Change and persistence in the European Early Neolithic. Journal of Social Archaeology 1: 244-270.

2003. Materielle Kultur und Ethnizität - eine sinnlose Fragestellung? In U. Veit, T. Kienlin, C. Kümmel and S. Schmidt (eds.), Spuren und Botschaften: Interpretationen materieller Kultur. Waxmann. Münster: 205-223.

Spriggs M. 2013. Leaving safe harbours: movement to immobility, homogeneity to diversification. A comparative archaeological sequence from the western Pacific. In S. Bergerbrant, S. Sabatini (eds.), Counterpoint. Essays in Archaeology and Heritage Studies in honour of Professor Kristian Kristiansen. British Archaeological Reports IS 2508. Archaeopress. Oxford: 549-556.

2016. Lapita and the Linearbandkeramik: what can a comparative approach tell us about either? In L. Amkreutz, F. Haack, D. Hofmann and I. van Wijk (eds.), Something out of the ordinary? Interpreting diversity in the Early Neolithic Linearbandkeramik and beyond. Cambridge Scholars Publishing. Newcastle: 481-504.

Stehli P. 1994. Chronologie der Bandkeramik im Merzbachtal. In J. Lüning, P. Stehli (eds.), Die Bandkeramik im Merzbachtal auf der Aldenhovener Platte. Rheinland Verlag. Köln: 79-191.

Strien H.-C. 2005. Familientraditionen in der bandkeramischen Siedlung bei Vaihingen/Enz. In J. Lüning, C. Frirdich and A. Zimmermann (eds.), Die Bandkeramik im 21. Jahrhundert. Symposium in der Abtei Brauweiler bei Köln vom 16.9.-19.9.2002. Marie Leidorf. Rahden: 189197. 
2009. Die 'jüngerbandkeramische Gruppenbildung' ein Requiem. In A. Zeeb-Lanz (ed.), Krisen - Kulturwandel - Kontinuitäten. Zum Ende der Bandkeramik in Mitteleuropa. Beiträge der internationalen Tagung in Herxheim bei Landau (Pfalz) vom 14.-17.06.2007. Marie Leidorf. Rahden: 213-217.

Strien H.-C., Gronenborn D. 2005. Klima- und Kulturwandel während des mitteleuropäischen Altneolithikums (58./ 57.-51./50. Jahrhundert v. Chr.). In D. Gronenborn (ed.), Klimaveränderung und Kulturwandel in neolithischen Gesellschaften Mitteleuropas, 6700-2200 v. Chr. Verlag des Römisch-Germanischen Zentralmuseums. Mainz: 131149.

Szécsényi-Nagy A., Keerl V., Jakucs J., Brandt G., Bánffy E. and Alt K. W. 2014. Ancient DNA evidence for a homogenous maternal gene pool in sixth millennium cal BC Hungary and the central European LBK. In A. Whittle, P. Bickle (eds.), Early farmers. The view from Archaeology and science. 0xford University Press. 0xford: 71-93.

Thomas J. 1996. The cultural context of the first use of domesticates in continental central and northwest Europe. In D. R. Harris (ed.), The origins and spread of agriculture and pastoralism in Eurasia. University College London Press. London: 310-322.
Urry J. 2007. Mobilities. Poliy Press. Cambridge.

Van de Velde P. 2008. The foam that flies ahead of a wave of advance: thoughts on the early Neolithisation of the Lower Rhine area uplands. In H. Fokkens, B. Coles, A. Van Gijn, J. P. Kleijne, H. H. Ponjee and C. G. Slappendel (eds.), Between foraging and farming. An extended broad spectrum of papers presented to Leendert Louwe Kooijmans. Analecta Praehistorica Leidensia 40. Leiden University Press. Leiden: 99-110.

Whittle A. 2003. The archaeology of people. Dimensions of Neolithic life. Routledge. New York.

Zeeb-Lanz A. 2009. Gewaltszenarien oder Sinnkrise? Die Grubenanlage von Herxheim und das Ende der Bandkeramik. In A. Zeeb-Lanz (ed.), Krisen - Kulturwandel Kontinuitäten. Zum Ende der Bandkeramik in Mitteleuropa. Beiträge der internationalen Tagung in Herxheim bei Landau (Pfalz) vom 14.-17.06.2007. Marie Leidorf. Rahden: 87-101.

Zimmermann A., Meurers-Balke, J. and Kalis, A. 2005. Das Neolithikum im Rheinland. Bonner Jahrbücher 205: 163. 
